\title{
The Role of Drama in Foreign Language Teaching
}

\author{
Bünyamin Celik ${ }^{1}$ \\ ${ }^{1}$ Department of Languages, Ishik University, Erbil, Iraq \\ Correspondence: Bünyamin Celik, Ishik University, Erbil, Iraq. \\ Email: bunyamin.celik@ishik.edu.iq
}

Received: April 3, 2019

Accepted: May 25, 2019

Online Published: June 1, 2019

doi: 10.23918/ijsses.v5i4p112

\begin{abstract}
This research was conducted to indicate the role of drama in foreign language teaching. First, the role of drama in general, its place in education and its role and use in foreign language teaching are given in the study. The study was conducted with 32 students in 2 different classes at the intermediate level at Ishık University. During the research, the same book and the same units, namely 4 units of Face2Face Intermediate, Cambridge University Press, was taught to the students of the control group and also the experimental class according to the annual plan determined by a lecturer. The students of the Control class were taught according to the instructions of the teachers' books in the related units of the book, but some subjects in the other experimental group were taught with drama activities in the units. At the end of the unit, the Progress Test Results of the course-book were compared. Subsequently, feedback was obtained from Experimental group students and 6 of them were published in the study without any changes and the results were evaluated accordingly.
\end{abstract}

Keywords: Drama in Foreign Language Learning, Process Drama, Foreign Language Teaching

\section{Introduction}

Apart from the traditional knowledge-centered and plain knowledge transfer approach, drama is a human-centered, method-based educational tool focusing on Romantic emotion and thought that provides a more emotional and sympathetic information exchange emphasizing the importance and uniqueness of the individual's character. Drama is a method that can be used in many different areas. A wide range of areas from economics, politics, industry, human relations to foreign language courses, physics and mathematics use drama. Drama art education is also used in the fields of teacher education, training of drama teacher, police training, military training, cook training and also training for problem solving methods (Fulford, Hutchings, Ross, \& Schmitz, 1990).

Educational drama has naturally taken its place in foreign language teaching. Many of the language teaching methods address to the cognitive aspect of teaching. However, since language teaching is a process in which grammar and vocabulary teaching as well as emotions, thoughts and cultural expressions are involved, the experiences gained through drama provide a better language acquisition and teaching environment by revealing the mental and physical qualities of the students in foreign language teaching. Viola Spolin (1963), in her book Improvisation for the Theatre quotes that "We learn through experience and experiencing, and no one teaches anyone anything". Drama provides an excellent platform for exploring theoretical and practical aspects of the English language (Whiteson, 1996). 
Wessels (1987) claims that drama is doing, drama is being and also stresses that "students learn through direct experience" (p.7). Drama is learning by doing. The individual adopts numerous roles in daily life and communicates according to his / her roles. As Shakespeare said: "All the world's a stage, and all the men and women merely players". Drama aims at giving the emotional content and body to the language. The main purpose of using drama in a foreign language is to emphasize "meaning". It is undeniable that the right structures need to be taught, but what is important is to teach them in a meaningful way from the beginning (Maley \& Duff, 1982, p.7). Wessels (1987) also claims that "drama requires meticulous planning and structuring" (p. 15).

One of the most important changes that drama offered in foreign language teaching is undoubtedly the changes in teacher and student roles. Thanks to drama, these two figures have completely been exempt from their classic roles and enter into by far a more free and comfortable relationship in the classroom. Particularly thanks to the change in the role of the teacher, the motivation required for learning becomes higher. Because of the changing effect of drama activities, the teacher is no longer the only ruler of the class who is considered to be privileged to know everything and is not anymore a figure who provides discipline by intimidating. It is the person who conducts activities, plays games and is consulted when necessary. Therefore, the student will be able to use the foreign language without being afraid of the authority stress and making mistakes.

There are many good reasons why it should be applied efficiently with students of almost every age group and level of foreign language when some of the necessary regulations for the successful implementation of the drama activities are taken into consideration. The environment and duration of the activities, elaborating on the words and sentences related to the target topic beforehand, encouraging the students in the positive direction and supporting them in the classroom environment and the repetition of experiences and practices more frequently will reveal a more successful language acquisition. The main goal of this study is to show that students are gaining the foreign language more efficiently by using the specified drama techniques and tools during foreign language learning.

\subsection{Research Questions}

- Do drama lessons improve student motivation?

- Do they contribute to students' speaking skills?

- Can students overcome their anxieties during communication through these activities?

- Are these lessons useful enough to boost vocabulary?

\subsection{Hypothesis}

It is hypothesized that drama lessons will greatly increase the student motivation to the language learning, because it is apparent that psychological barriers are detrimental to improving a foreign language. When a friendly and warm atmosphere is created, the students' participation is expected to increase, which will make learning easier. 


\section{Review of Literature}

\subsection{Drama in Foreign Language Learning}

With the emergence of new searches on foreign language teaching, the use of drama has naturally taken its place in this field. Drama activities open the doors of the classroom to the outside world and provide students with a communication environment limited to their imagination. In other words, through drama, situations and environments are created for the students to communicate naturally by going out of the classroom. With this feature, drama studies are a practical and convenient tool in speaking classes (Mart, 2018; 2019).

Susan Holden (1981) gave many definitions of what drama is and how it provides opportunities to a person to express themselves, and has played a crucial role in the continuous development of drama in the educational field. Drama is one of the most powerful weapons in communication developments and in teaching. Drama events are interpreters, memory helpers and instructive. Drama takes its power from three elements and is therefore an effective tool in teaching. First of all, drama activities ensure that the right and left parts of the brain which control logic and creativity to collaborate. It requires simple active experiences, a way of learning. However, it includes four basic language skills. This enables more efficient results in foreign language teaching (Hoskisson \& Tompkins, 1987).

According to Maley and Duff (1982), a work program that considers body-mind bonding should be applied regardless of the problems encountered in learning foreign languages. Drama, which contains a lot of physical activity, is a very suitable tool for this kind of learning. Drama activities include the words and expressions we use in daily life. In the developing and rapidly populating world, some of the expressions used by individuals in daily life are stereotyped. For example, when we are bored, a greeting or thanking takes place without feeling most of the time, like mechanics. Drama, in contrast to this aspect of everyday life, restores the moments we live in.

Drama for second language learners can provide an opportunity to develop the imagination of the students. The students can go beyond the here and now and even 'walk in the shoes' of another. It provides an opportunity for independent thinking (McCaslin 1996). In drama activities, the person feels the energy he / she lost through feeling. Thus, the person in the learning stage can break the patterns and gain different approaches. He/she realizes the things that should be in real life. Heathcote (1990) considered drama as an important learning method. It uses drama to help students not to create games but to raise awareness of them, to look at reality through fantasy, and to see what is behind their appearance. What drama does is not to give students more information but to gain the ability to use what they know.

Students learn how the texts of speech are listed in the language they learn with drama, how they use expressions according to the situation, how the relations are expressed. If the dialogues are read and played in class, the students will be able to comprehend certain expressions and learn how to pay attention to such elements as pronunciation, intonation, and body language. According to Whiteson and Horovitz (1998), teachers state that playing some parts of the game in the classroom increases the communication and collaboration. The motivation of the students increases because they have an active role in the learning process. Moreover, when they study about a situation from real life, mental and 
emotional motivation is provided. In this way, students are able to share their experiences and achieve sympathy with others.

\subsection{Main Drama Techniques and Tools in Foreign Language Teaching}

In the language teaching, it has been revealed that many of the techniques that emphasize creativity bring successful results. Wessels points out that 'drama games' should "involve action, exercise the imagination, and involve both 'learning' and 'acquisition' and permit the expression of emotion." (1987, p.29) The use of these techniques increases the motivation of the students and makes the course more efficient.

Drama in foreign language teaching uses techniques like improvisation, role playing, pantomime and puppets and many other tools. These are the techniques that are frequently used in all activities of foreign language teaching with drama.

\subsection{Improvisation}

Improvisation is the creation of situations where characters speak spontaneously. Improvisation reveals the language skills of the students and tests the communication features. They are natural instant reactions. While putting the improvisation into action in foreign language teaching, dialogues should be short. The more the student gets used to the game, more fluid and longer the dialogues become. Although the events and situations in the play are given in advance, the characteristics and emotions of the characters in the game are acted out naturally by the player, and the dialogues are created and the students feel it, too. For example, it is similar to how naturally conversation begins with the person sitting next to you in a long train or bus ride. In order to make the student get used to improvisation, only a part of a story can be developed with various accessories such as costumes, masks, and so on, helping the student maximize his / her linguistic ability.

\subsection{Role Play}

Role playing is simply a way for students to take on the role of fictitious characters and to talk and behave as they think these people may talk or do (Watcyn-Jones, 1983). Students can play the joyful, excited, sad, tired or happy states of a character in a piece. Different characters are animated by students with different features, like an excited mother, tired father and happy child. Then these characters can be combined around an event. Through role-playing, a wide variety of experiences can be gained in the classroom environment. Communication games go far beyond just a pair work or group work. Through role playing, students can gain the ability to speak and communicate in every situation. Some people learn foreign languages to prepare themselves for certain roles. It will be useful for the students to try different uses of the language they need in future in a safe environment, namely in class. Role-playing is a very important rehearsal for real life preparation, allowing students to learn not only certain patterns, but also how to communicate in different situations (Weinert \& Kluwe, 1987).

Role-playing helps shy students by providing a mask to them. Students who are ashamed to talk about their own experiences may choose to play a role. The most important feature of role playing is that it is fun for children. The students work on their imagination. Learning while having fun will also attract non-interested students as well (Blatner, 1994). 


\subsection{Mime Technique}

Mime or pantomime is a drama made only by movements without using words or sounds. Many foreign language teachers use mime techniques without even being aware of it. Mime techniques are used in order to convey the correct meaning when words are inadequate, especially when teaching a new word peculiar to a certain culture. Rhythmic practices based on imitation in movement rehearsals are considered as preparation for mime technique. The rhythmic movements of those who act out in the drama play instead of someone other than themselves, make these movements dramatic and as a result the pantomime occurs.

This technique ensures that non-verbal tools can be used to communicate with students. The activities in which paralinguistic communication elements such as facial expressions, gestures, and body movements are emphasized can be supported with parallel studies where appropriate words are added. In such studies, it is not intended to replace the non-verbal communication tools but to develop these elements (Holden, 1981). Moreover, grammar topics such as verbs or prominent adjectives can be taught or reinforced through the mime.

\subsection{Instruments and Tools}

Drama activities are mostly performed with music. For this reason, the most commonly used tools are any kind of musical instruments and players. Visual tools such as pictures, photographs, posters, writings, display boards; cartons, drawings papers, puppets, colored crayons, toys, ornaments, boxes, vases, old clothes, damaged real items such as shoes; printed materials such as newspapers, articles, announcements, photographs, news that are cut off from various newspapers and magazines, books, magazines, newspapers, posters, brochures, household items; devices such as computers are important.

One of the most important benefits of puppet use in foreign language teaching is that shy or troubled students can overcome the problems of expressing themselves in the target language by entering the character of the puppet. The area where puppets are most effectively used for teaching purposes is undoubtedly language learning. Because there is unprepared speech in puppetry; the advantage of the puppet is to hide the person who is speaking and allow the people to communicate who are limited in terms of verbal abilities or shy. It is important to ensure that the equipment to be used in the drama is suitable for the financial situation of the participants (students), easy to find, not to harm them, can be used for many purposes, and does not restrict the working areas.

\section{Research Methodology}

\subsection{Design of the Study}

Qualitative and quantitative methods were used in this research both in order to analyze the results and to observe the credibility of the findings. This study is an experimental design and it tries to check the hypothesis through applying drama techniques into the class sessions. In the end, the success was measured through tests given to the students. The students' ideas were also noted down to check the validity of the use of drama techniques. Although it is easy to assess student success through tests, it is not possible to observe behavioral changes and psychological effects of the lessons, so student interview was also used to observe these changes. 


\subsection{Sample Selection}

All students participating in the study are Ish1k University Preparatory School students. According to a proficiency test conducted by the University, the English level of the students was determined. The students were proficient in English at Intermediate level and had English lessons during their education in their previous schools. 32 students who have the same English background and have Intermediate level were randomly selected from 3 different classes from the two participant groups. The two groups were informed about how to take the lessons and why they would be taken as such. Students agreed and they were informed that they have the right to leave the classes at any time. Both groups were trained according to the schedule prepared by Ishik University Preparatory School with equal number of lessons and duration on different days of the week by a lecturer.

\subsection{Procedure and Data Collection}

Two groups, Control and experimental, were created. Both groups had 16 students with the same level of English and background. In both groups, the same 4 units (Unit 6, 7, 8, 9) of Cambridge University Press Face2Face Intermediate were taught according to the annual plan determined in 4 weeks. At the end of the unit, weekly Progress Tests belonging to the related units in Face2Face Intermediate book were made. The Control group has been taught in accordance with the guidelines recommended by the teacher's book of the Face2Face Intermediate book and the publishing house. Progress Test results of weekly units are given in the tables. The results are compared and interpreted.

In addition to the guidelines recommended by the teacher's book and publishing house, the students of the Experimental group were taught the subjects stated below with the drama techniques and tools by the same lecturer during the same time and course hours as the control group. In contrast to the control group, experimental group students were advised to prepare themselves for the drama activities in the departments specified in the units except for the course hours. They were also told that they could get help from the instructor for the planned drama activities. The instructor encouraged the students in this group for the determined drama activities and gave them advice and guidance about the practices. The Weekly Progress Test results are presented in Tables 1,2, 3 and 4. The results are compared and interpreted in the conclusion section.

\subsubsection{Curriculum for Experimental Group - Drama Techniques and Tools}

Course Book: Cambridge University Press Face2Face Intermediate - every class lasts 50 minutes.

Unit 6: 6A - Teenagers, Speaking and Reading, 4, Living with the Enemy: Improvisation activity Poster - hat - music - 15 minutes

6B - Roles People Play, Vocabulary and Speaking 1, 2: Role Play activity - Poster - Dress Music - Recorder - 15 minutes

6C - Family Business, Speaking and Reading, 3: Improvisation activity - Poster -MagazineOccupational Clothes - 15 minutes

Unit 7: 7A -50 places to go - Reading and Speaking, 2, 3, Places to Go Before You Die: Improvisation activity - Poster - Traditional clothes- brochure - 15 minutes 
7B - What are you taking?, Speaking and Vocabulary,1, 2, 3, Thinks we take on holiday: Role Play activity - Poster - Luggage - Various clothes and items- Brochure - Music 15 minutes

7D - It doesn’t work, Real Word, 1,2,3,4, Role Play activity, Poster - Music 15 minutes

Unit 8: 8A - Home sweet home, Reading, Listening and Speaking, Describing your home, 3, 4 Improvisation and Mime activities - Poster - Music - Some household items 20 minutes

8B - Meet parents, Listening and Speaking, 8, 9, Role Play activity - Poster - Music - Some kitchen utensils, glass, fork etc. 15 minutes

8C - Cultural differences, Reading and Speaking, Culture shock! , 4, Role Play and Improvisation activities - Music - Poster - Puppet - some traditional clothes and household items 20 minutes

Unit 9: 9A - Problems, Problems, Listening, 3, Role Play and Improvisation activities - Music - Poster - Brochure - Puppet -Some clothes and items 20 minutes

9B - Sleepless nights, Listening and Speaking, 3, 4, 5, Role Play and Improvisation activities Music - Baby puppet - Some clothes and baby items 20 minutes

9D - Invitations, Real world, 1, 2, Role Play activity - Poster -Clothes and items - Music 15 minutes

\section{Results and Discussions}

We reached some results at the end of four weeks. The results are as follows:

\subsection{First Week}

Table 1: Over 100 / Score of the Progress Test - Unit 6 in the control and experimental groups Unit 6 in the control and experimental groups

\begin{tabular}{|l|c|c|}
\hline \# & $\begin{array}{c}\text { Control } \\
\text { Eroup }\end{array}$ & $\begin{array}{c}\text { Experimental } \\
\text { Group }\end{array}$ \\
\hline Student 1 & 91 & 94 \\
\hline Student 2 & 82 & 84 \\
\hline Student 3 & 75 & 83 \\
\hline Student 4 & 74 & 78 \\
\hline Student 5 & 74 & 77 \\
\hline Student 6 & 73 & 76 \\
\hline Student 7 & 70 & 75 \\
\hline Student 8 & 68 & 75 \\
\hline Student 9 & 66 & 71 \\
\hline Student 10 & 65 & 68 \\
\hline Student 11 & 65 & 66 \\
\hline Student 12 & 63 & 65 \\
\hline Student 13 & 62 & 64 \\
\hline Student 14 & 48 & 62 \\
\hline Student 15 & 40 & 48 \\
\hline Student 16 & 33 & 45 \\
\hline Average & 65.6 & 70.7 \\
\hline
\end{tabular}


At the end of the first week, unit 6 was completely finished and according to the progress test results at the end of the unit, the control group had 65.6 points out of 100 and the experimental group had 70,7 out of 100 .

\subsection{Second Week}

Table 2: Over 100 / Score of the Progress Test - Unit 7 in the control and experimental groups

\begin{tabular}{|l|c|c|}
\hline$\#$ & $\begin{array}{c}\text { Control } \\
\text { Group }\end{array}$ & $\begin{array}{c}\text { Experimental } \\
\text { Group }\end{array}$ \\
\hline Student 1 & 94 & 96 \\
\hline Student 2 & 83 & 94 \\
\hline Student 3 & 76 & 92 \\
\hline Student 4 & 75 & 88 \\
\hline Student 5 & 73 & 86 \\
\hline Student 6 & 73 & 86 \\
\hline Student 7 & 71 & 85 \\
\hline Student 8 & 70 & 80 \\
\hline Student 9 & 70 & 78 \\
\hline Student 10 & 66 & 77 \\
\hline Student 11 & 65 & 75 \\
\hline Student 12 & 65 & 75 \\
\hline Student 13 & 64 & 70 \\
\hline Student 14 & 60 & 68 \\
\hline Student 15 & 58 & 57 \\
\hline Student 16 & 55 & 55 \\
\hline Average & 69.9 & 78.9 \\
\hline
\end{tabular}

At the end of the second week, unit 7 was completely finished and according to the progress test results at the end of the unit, the control group had 69.9 points out of 100 and the experimental group had 78,9 out of 100 .

\subsection{Third Week}

Table 3: Over 100 / Score of the Progress Test - Unit 8 in the control and experimental groups 


\begin{tabular}{|l|c|c|}
\hline & Control & Experimental \\
\hline \# & Group & 92 \\
\hline Student 1 & 90 & 96 \\
\hline Student 2 & 88 & 86 \\
\hline Student 3 & 84 & 86 \\
\hline Student 4 & 81 & 84 \\
\hline Student 5 & 78 & 82 \\
\hline Student 6 & 72 & 80 \\
\hline Student 7 & 71 & 78 \\
\hline Student 8 & 70 & 74 \\
\hline Student 9 & 68 & 71 \\
\hline Student 10 & 67 & 70 \\
\hline Student 11 & 66 & 70 \\
\hline Student 12 & 66 & 68 \\
\hline Student 13 & 60 & 68 \\
\hline Student 14 & 58 & 65 \\
\hline Student 15 & 50 & 62 \\
\hline Student 16 & 50 & 77.0 \\
\hline Average & 69.9 & \\
\hline
\end{tabular}

At the end of the third week, unit 8 was completely finished and according to the progress test results at the end of the unit, the control group had 69.9 points out of 100 and the experimental group had 77,0 out of 100 .

\subsection{Fourth Week}

Table 4: Over 100 / Score of the Progress Test_Unit 9 in the control and experimental groups

\begin{tabular}{|l|c|c|}
\hline \# & $\begin{array}{c}\text { Control } \\
\text { Eroup }\end{array}$ & $\begin{array}{c}\text { Experimental } \\
\text { Group }\end{array}$ \\
\hline Student 1 & 95 & 96 \\
\hline Student 2 & 80 & 95 \\
\hline Student 3 & 80 & 95 \\
\hline Student 4 & 78 & 92 \\
\hline Student 5 & 72 & 87 \\
\hline Student 6 & 70 & 85 \\
\hline Student 7 & 70 & 80 \\
\hline Student 8 & 70 & 78 \\
\hline Student 9 & 66 & 75 \\
\hline Student 10 & 64 & 75 \\
\hline Student 11 & 64 & 72 \\
\hline Student 12 & 62 & 70 \\
\hline Student 13 & 60 & 70 \\
\hline Student 14 & 55 & 68 \\
\hline Student 15 & 52 & 59 \\
\hline Student 16 & 52 & 58 \\
\hline Average & 68.1 & 78.4 \\
\hline
\end{tabular}


At the end of the fourth week, unit 9 was completely finished and according to the progress test results at the end of the unit, the control group had 68.1 points out of 100 and the experimental group had 78,4 out of 100 .

\subsection{General Average of Four weeks}

Table 5: Over 100 / Score of the all Units Progress Tests Average in the control and experimental groups

\begin{tabular}{|c|c|c|}
\hline \# & $\begin{array}{l}\text { Control } \\
\text { Group }\end{array}$ & $\begin{array}{l}\text { Experimenta } \\
\text { I Group }\end{array}$ \\
\hline $\begin{array}{l}\text { Over } 100 / \text { The Average of the } \\
\text { Progress Test - Unit } 6\end{array}$ & 65.6 & 70.7 \\
\hline $\begin{array}{l}\text { Over } 100 / \text { The Average of the } \\
\text { Progress Test - Unit } 7\end{array}$ & 69.9 & 78.9 \\
\hline $\begin{array}{l}\text { Over } 100 / \text { The Average of the } \\
\text { Progress Test - Unit } 8\end{array}$ & 69.9 & 77 \\
\hline $\begin{array}{l}\text { Over } 100 / \text { The Average of the } \\
\text { Progress Test - Unit } 9\end{array}$ & 68.1 & 78.4 \\
\hline $\begin{array}{l}\text { Over } 100 \text { / Average of the } 4 \\
\text { weeks Progress Test }\end{array}$ & 68.4 & 76.3 \\
\hline
\end{tabular}

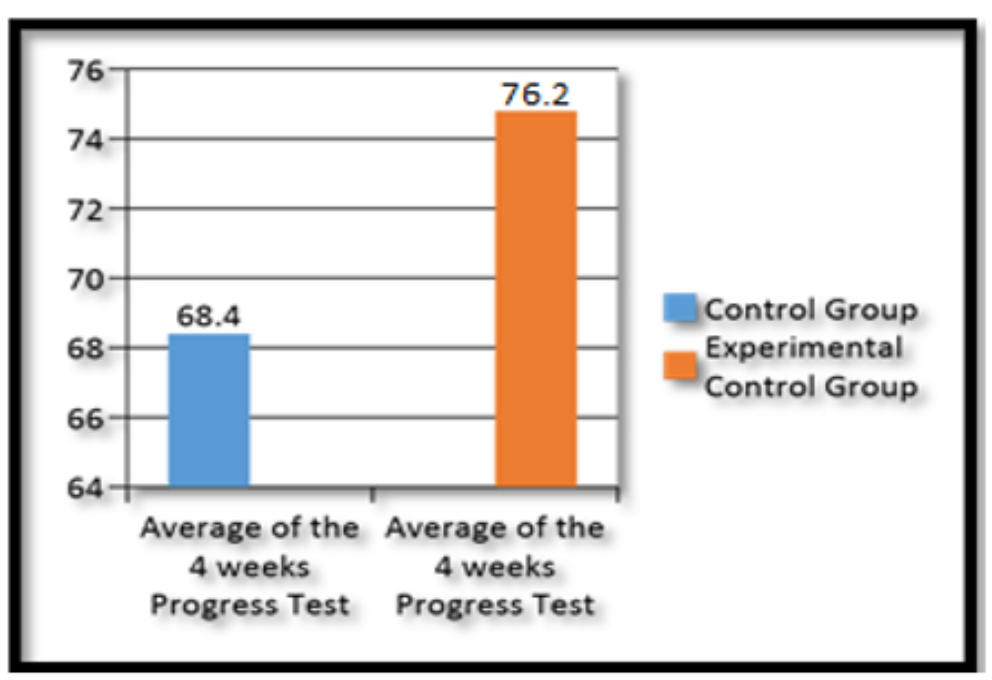

Figure 1: Over 100 / Score of the all Units Progress Tests Average in the control and experimental groups

\subsection{Experiment Result}

Results of the average of the Progress tests for the units carried out over the course of 4 weeks are shown in Table 1, 2, 3 and 4 for both groups. Results of the average of all the Progress tests performed at the end of 4 weeks are 68.4 out of 100 for the control group and 74.8 out of 100 for the experimental group students and shown in Table 5 and Figure 1. Obviously, it is seen that a better language acquisition is 
achieved as a result of the application of drama techniques and instruments during foreign language education.

\subsection{Students Feedbacks}

This evaluation includes the feedbacks and comments of experimental group students after applying drama, drama techniques and some specific tools to develop their foreign language within the class. At the end of this application, it is asked to write their own comments about drama by students (See Appendix A).

Student 1: Because of my father's work, I studied at different times in different schools and I had the chance to experience many different English teachers and the teaching environment. I have previously studied English in different Course books, but in the last 4 weeks our lecturer has tried to teach us English with a system of drama activities that we can express ourselves better. Although it was a bit strange at first, it was very interesting for us to participate in drama activities. Later I desired more to participate in the activities. Apart from the classical course, these activities made the lesson more interesting. I would like to thank my teacher for choosing me for this class and introducing me to this experience.

Student 2: I can't tell you how happy I am to be in this class. I have a slightly less social and quiet personality than my other friends. Therefore, my biggest problem in the English language is to express myself, I was having some speech problems too. Our teacher's drama and drama activities and their use in drama lessons in the beginning were a little intimidating, I should say. During the first two weeks, I did not participate in any activity despite my teacher's insistence. But I found myself in a short role in a cook's outfit about a profession. I enjoyed it so much that I can't explain enough. I only had a very short preparation for just 15 minutes. Then I found myself in the class on the stage and said everything that comes to my mind. It had been a completely different experience. Next I tried to participate in all the activities more or less. I would like to thank our teacher.

Student 3: I had the opportunity to learn more about drama in this class. I thought it was just a romantic movie. It later turned out that it was a way to a door that opens to a larger world. I shared some of the work we did in the class on social media and received some amazing responses. This encouraged me further and became a member of our university's theatre club. I love English as a lesson, but now I feel I'm living in English. I would like to thank our teacher for making me love this class and teaching me the drama that led me becoming a social media phenomenon.

Student 4: The lessons in the last week were really interesting. We learned what drama is and how to use it in the classroom. It was a different experience. At first, my friends and I were a little nervous. In fact, we didn't want to be embarrassed in front of our girl friends in class. But it wasn't like that. When we started to use English with the drama activities in the class, we found that it was very fun and different for everyone. Sometimes we memorized with our friends and sometimes we had improvised activities in the class and felt that my English was going a step further. I wish I had this drama activity in other courses. Thank you... 
Student 5: I had two years in the theatre club in high school so my familiarity grew more with drama and plays. I was very happy to see it again in a foreign language class at university. I especially helped my friends who didn't know much about drama and drama activities. I supported our teacher in his efforts to encourage them and took part in many activities. For our class, we were preparing posters and other related things. We also found outfits and some household items for the plays. This process was very enjoyable and a nice experience. I also saw that I started to use English for the first time that much. This has led to a positive level of my lessons and test results. I would like to thank our teacher. Please let us continue this kind of activities...

Student 6: I was learning English a little hard. I think it's really hard for me to learn a foreign language. Although I had many positive feelings about English before, I really noticed that our teacher enriched our lessons with drama and activities. "What is this?", I said initially and then I found myself at the center of the attention of the class with a hat on my head as a family father I was playing. I realized that I really enjoyed this activity, and I started to study English to take part in other activities. After a while, I realized that I could learn English. I'm even talking and improvising. I would like to thank to my teacher for the drama activities and he believed in me and so he changed my perspective on English and developed my foreign language.

\section{Conclusion}

The focus of this study is on the role of drama techniques and tools in foreign language teaching and its use in the classroom. By integrating different drama techniques into simple activities in a course book followed in a foreign language learning, it has been observed that it is usable in the classroom and contributes to the roles of the teacher and the student, and to their general motivation.

Drama in foreign language teaching is seen as a technique for communicator language teaching. Drama is not a new language teaching theory, such as a communicative approach, but rather a technique used to develop specific language skills. As it is clear from the feedback from the students, drama helps the target language to be understood and decoded more easily. Thus, the students will eliminate the prejudice against foreign language. As a matter of fact, a deeper experience in language acquisition by focusing on students in the classroom environment has emerged in progress tests and in positive student feedbacks.

Drama needs careful planning and structuring. In this context, the teacher has a large organization role. The material the teacher chooses for the activity should satisfy the student's interests and skills, meet his needs, and be appropriate to his / her age and gender. The color, physical properties and functions of the chosen material should be multifaceted and should be supportive for various areas of development (linguistic, cognitive, social, emotional, etc.).

The most important feature of drama is that it is fun for students. Preparation with games, mime and improvisation will help the student to decrease the tension and the motive will increase. In warm-up studies, touching and physical contact will help to have a happy group by eliminating obstacles and shyness among students. Through the drama technique, the class environment, full of customary desks and tables, is transformed into a space that can be moved easily. Events give students the opportunity to talk and express themselves. Thus, children feel that they are important for the event. 
What is more important than all of this is that drama is based on human beings and it is a psychological method. This feature also eliminates the fears occurring during foreign language teaching. When shy and withdrawn students need to memorize and transfer, they are frightened and stressed because of the questions asked to them. However, with the technique of drama or group work, such students can find an environment where they can express themselves comfortably. Because of all these features, the drama technique is suitable for students at all levels, starting from the new learners of the foreign language.

\section{Limitations of the Study}

The first limitation of this study is that it was only applied in one school and among its students. Since drama requires friendly atmosphere, it gives the best results among close peer groups. The students of this prep. School have known each other for a long time and they have already developed very good conduct among themselves. In case it is applied to the groups who have formal relations, it may not give similar results.

The age group is another limitation. This age group is more easily socialized and form friendly bonds easily. Younger groups may not give similar results especially because they are more inclined to be shy. Another thing should focus on the level of the students. In case it is applied to other levels, it may give different results especially because their proficiency level may not be compatible with these activities.

Teachers as conductors are not professionals about drama and it may render another limitation. The teacher may not have designed the lesson in a desired way or there may have been better style to teach.

\section{References}

Blatner, A. (1994). Acting for real: Drama therapy process and technique. By R. Emunah. New York: Brunner/Mazel.

Fulford, J., Hutchings, M., Ross, A. \& Schmitz, H. 1990. Bright ideas: Drama. Scholastic Publications Ltd.

Holden, S. (1981). Drama in language teaching. Essex: Longman.

Hoskisson, K., \& Tompkins, G. E. (1987). Language arts: Content and teaching strategies. Merrill Publishing Company, Columbus, Ohio.

Maley, A., \& Alan D. (1982). Drama techniques in language learning: A resource book of communication activities for language teachers. Cambridge: Cambridge University Press.

Mart, C.T. (2018). Literature in the language classroom: A recipe to maximize learning. L1 Educational Studies in Language and Literature, 18, 1-25.

Mart, C.T. (2019). Reflections on discussions of literature: A language learning environment to promote speaking skills. The Journal of Social Sciences Research, 5(4), 846-850.

McCaslin, N. (1996). Creative drama in the classroom and beyond. London, Longman Publishers Spolin, V. (1963). Improvisation for the theater. Evanston. ILL: Northwestern University Press.

Watcyn-Jones, P. (1983). “Act English” A Book of Role-plays. Penguin Books

Weinert, Franz E., \& Rainer H. K. (1987). Metacognition, motivation and understanding. Hillsdale, NJ: Lawrence Erlbaum.

Wessel, C. (1987). Drama. Oxford: Oxford University Press.

Whiteson, V., \& Horovitz, N. (1998). The play's the thing. NewYork: St. Martin's Press.

Whiteson, V. (1996). New ways of using drama and literature in language teaching. Alexandria,VA., TESOL. 


\section{Appendix A}

Dear Participants,

During to four weeks, you have experienced with the different way of drama, drama techniques and some specifically tools to develop second foreign language within the class. We asking to share with us positive and negative opinions about the aspects of this method.

Thank you for participating in this evaluation questionnaire.

(Depending on your request, Name and Surname) 